\title{
The impact of initial oral health training on teacher's knowledge, attitudes, and actions change
}

\author{
Anne Agustina Suwargiani*, Riana Wardani*, Netty Suryanti*, Asty Samiaty Setiawan* \\ *Department of Public Health Faculty of Dentistry Universitas Padjadjaran
}

\begin{abstract}
Introduction: Formal education is the main place for children to improve their knowledge. Teachers are the sources of information which is easily received by children, so the teacher's role in children's education is very important. Oral health training able to improve the skills and information resource in a community. Teachers, as the trainee, can play a role in improving the access to information regarding oral health. The objective of this research was to assess the knowledge, attitude, and practice of the teachers before and after the performance of initial training on oral health care. Methods: Questionnaires, with the research variables were knowledge, attitude, and practice of oral health care. The study population was Arraffi Elementary School teachers. The sampling technique was total sampling. The data collecting was done by distributing questionnaires and self-report before and after training. Results: Wilcoxon test shown that P-value pretest and posttest of knowledge was 0.675 , attitude was 0.354 , and practice was 0.129 . Knowledge regarding oral care showed an increasing in achievement percentage. Posttest results of attitude showed the increase in the percentage of positive and negative statements. Posttest results on practice showed some behavior having an increasing percentage, but one behavior remain unchanged. There was no significant difference of knowledge, attitude and practice before and after initial training. Conclusions: There was no impact of initial oral health training on teacher's knowledge, attitudes, and actions change.
\end{abstract}

Keywords: Knowledge, attitude, practice, teacher, training

P-ISSN 1979-0201, e-ISSN 2549-6212 Available from:http://jurnal.unpad.ac.id/pjd/index

DOI:http://dx.doi.org/10.24198/pjd.vol29no1.11596

Submission: August 2017 Publishing : March 2017

\section{INTRODUCTION}

The role of school is highly important in the process of creating the habit of maintaining children oral health. Formal education is the main place of a child to increase his/her knowledge. Teachers and peers are the sources of information which are easily obtained by the children, so the role of teachers and peers is very important. Oral health education should be given repeatedly and attractive to children in schools, therefore a good synergy between health care workers, students, teachers, and parents are highly needed. ${ }^{1}$

Synergy between health care workers and teachers in oral health school program is one of the efforts taken in public health field. It is 
aimed to maintain and to improve oral health of the students at schools, and the specific goal is to increase the participation of teachers to do promotive and preventive actions towards oral health. One of this implementation is the conducting of quarterly mass tooth brushing using fluoride-contained toothpaste by school health program. $^{2}$

Oral health training able to improve the skills and information resources in a community. In this case, teachers as trainee can play a role in improving information access on oral health behaviour. ${ }^{3}$ Some research stated that education and training of trainees were able to provide effective results in improving knowledge, attitudes and practice ${ }^{3-5}$, therefore the trainees were capable to give information and motivate people to adopt healthy behaviors. ${ }^{6}$

The above description encourages the conducting of a research on the difference of knowledge, attitude, and practice of elementary school teachers before and after the initial training of oral health care. The objective of the research was to assess the knowledge, attitude and practice of elementary school teachers, before and after the initial training of oral health care.

\section{METHODS}

The study population were teachers at Arraffi full day elementary school in Banjaran, Bandung Regency. The sampling methods used was total sampling because there were only small amount of people in the population. ${ }^{7}$ Data collection methods used was questionnaires that has internal and external validation with $R$ value at $0.596-0.674$. The questionnaire were given before and after training. Two-ways methods was used in this training. The training materials included oral health care for children and how to do that in school setting. The research variables were knowledge, attitude and practice of oral health care. Knowledge, attitude and practice studied was the achievement percentage that was expected to show at least eighty percent, as the reference of assessment benchmark. Data were tested by normality test.

\section{RESULTS}

The results of the pretest and posttest questionnaire before and after the initial training are presented in the Table 1 below:

The pretest and posttest results on the knowledge of the toothbrush and oral care shown an increase of the achievement percentage regarding the proper time to brush teeth. Knowledge about good habit like snacks that do not damage the teeth and the surface that should be brushed showed good percentage. Knowledge about how to clean plaque showed decreased percentage. Knowledge about flour can prevent cavities showed a constant percentage.

Post-test results in Table 2 showed that after initial training of dental health care showed the increase of the percentage on positive and negative statements. However, there was also a decrease of the percentage on positive statement, which was about the food selection.

Table 1. Teacher's knowledge

\begin{tabular}{lcccc}
\hline \multirow{2}{*}{\multicolumn{1}{c}{ Knowledge }} & Pretest & \multicolumn{2}{c}{ Posttest } \\
\cline { 2 - 5 } & $\mathrm{F}$ & $\%$ & $\mathrm{~F}$ & $\%$ \\
\hline How to clean plaque & 30 & 100 & 27 & 90 \\
Good habits & 30 & 100 & 30 & 100 \\
The right time to brush your teeth & 28 & 93.3 & 30 & 100 \\
Type of food that easily damage the teeth & 17 & 56.7 & 20 & 66.7 \\
Snacks that do not damage the teeth & 30 & 100 & 30 & 100 \\
The surface of the teeth that should be brushed & 30 & 100 & 30 & 100 \\
Fluor can prevent cavities & 20 & 66.7 & 20 & 66.7 \\
The occurrence of cavities & 19 & 63.3 & 23 & 76.7 \\
The things which are not included as the symptoms of cavities & 27 & 90 & 23 & 76.7 \\
\hline
\end{tabular}


Post-test results in Table 3 showed that teachers practice regarding teeth-brushing time and the use of fluoride-containing toothpaste had indicated an increase of percentage. However for the shared use of a toothbrush, it was indicated a constant percentage. A decrease could be seen in the percentage on brushing the posterior teeth on chewing surfaces. Normality test was used to determine normality distribution, which conducted with confidence level of $95 \%$. For data in the amount less than 50 used Shapiro Wilk test. ${ }^{8}$ Normality test results shown below the P-Value (0.05) as seen in Table 4, which indicated that data was not normally distributed.

Table 2. Teacher's attitude

\begin{tabular}{lccccc}
\hline \multirow{2}{*}{ Attitude } & \multicolumn{2}{c}{ Pretest } & \multicolumn{2}{c}{ Posttest } & \multirow{2}{*}{ Statement } \\
\cline { 2 - 5 } & $\mathrm{F}$ & $\%$ & $\mathrm{~F}$ & $\%$ & \\
\hline The presence of cavities that cause illness & 29 & 96.7 & 30 & 100 & Positive \\
The desire to do cavities filling & 22 & 73.3 & 30 & 100 & Positive \\
The feeling of bad-appearance if there are some cavities & 26 & 86.7 & 21 & 70 & Positive \\
Approval of the importance of control to the dentist every six months & 25 & 83.3 & 28 & 93.3 & Positive \\
Agreement not to go to the dentist if there is no illness & 16 & 53.3 & 2 & 6,7 & Negative \\
The habit of teeth-brushing while taking a bath & 3 & 10.0 & 7 & 23.3 & Positive \\
The agreement that night teeth-brushing should not be done & 26 & 86.7 & 26 & 86.7 & Negative \\
Shared-use of a toothbrush & 28 & 93.3 & 27 & 90 & Negative \\
Selection of food : nuts are better for teeth than sweets and sugary food & 12 & 40 & 9 & 30 & Positive \\
\hline
\end{tabular}

Table 3. Teacher's practice

\begin{tabular}{|c|c|c|c|c|}
\hline \multirow{2}{*}{ Practice } & \multicolumn{2}{|c|}{ Pretest } & \multicolumn{2}{|c|}{ Posttest } \\
\hline & $\mathbf{F}$ & $\%$ & $\mathbf{F}$ & $\%$ \\
\hline Teeth-brushing at night before sleep & 21 & 70 & 26 & 86.7 \\
\hline Teeth-brushing after breakfast & 15 & 50 & 24 & 80 \\
\hline Using a toothpaste containing fluoride & 27 & 90 & 30 & 100 \\
\hline Shared-use of a toothbrush & 28 & 93.3 & 28 & 93.3 \\
\hline \multicolumn{5}{|l|}{ How to brush the front teeth of the upper jaw } \\
\hline a. Back and forth & 14 & 46.7 & 9 & 30 \\
\hline b. Up and down & 12 & 40 & 17 & 56.7 \\
\hline c. Rotated & 4 & 13.3 & 4 & 13.3 \\
\hline \multicolumn{5}{|l|}{ Brushing the front teeth of the lower jaw } \\
\hline a. Back and forth & 17 & 56.7 & 14 & 46.7 \\
\hline b. Up and down & 7 & 23.3 & 14 & 46.7 \\
\hline c. Rotated & 6 & 20 & 2 & 6.7 \\
\hline \multicolumn{5}{|c|}{ Brushing the back teeth of the upper jaw surface near the cheek } \\
\hline a. Back and forth & 10 & 33.3 & 6 & 20 \\
\hline b. Up and down & 6 & 20 & 0 & 0 \\
\hline c. Rotated & 14 & 46.7 & 24 & 80 \\
\hline \multicolumn{5}{|c|}{ Brushing the back teeth of the upper jaw near the surface of the tongue } \\
\hline a. Back and forth & 16 & 53.3 & 11 & 36.7 \\
\hline b. Up and down & 6 & 20 & 19 & 63.3 \\
\hline c. Rotated & 8 & 26.7 & 10 & 33.3 \\
\hline \multicolumn{5}{|l|}{ Brushing the back teeth on chewing surfaces } \\
\hline a. Back and forth & 23 & 76.7 & 20 & 66.7 \\
\hline b. Rotated & 7 & 23.3 & 10 & 33.3 \\
\hline
\end{tabular}


Table 4. Test of normality

\begin{tabular}{lcc}
\hline \multicolumn{1}{c}{ Variable data } & $\mathrm{N}$ & $\mathrm{P}$ value \\
\hline Knowledge pretest & 30 & 0.001 \\
Knowledge posttest & 30 & 0.000 \\
Attitude pretest & 30 & 0.012 \\
Attitude posttest & 30 & 0.000 \\
Practice pretest & 30 & 0.127 \\
Practice posttest & 30 & 0.001 \\
\hline
\end{tabular}

Table 5. Hyphotesis testing used wilcoxon test rank

\begin{tabular}{lcl}
\hline \multicolumn{1}{c}{ Variable data } & P Value & \multicolumn{1}{c}{ Decision } \\
\hline $\begin{array}{l}\text { Knowledge pretest } \\
\text { and posttest }\end{array}$ & 0.675 & $\begin{array}{l}\text { Retain the null } \\
\text { hypothesis }\end{array}$ \\
$\begin{array}{l}\text { Attitude pretest and } \\
\text { posttest }\end{array}$ & 0.354 & $\begin{array}{l}\text { Retain the null } \\
\text { hypothesis }\end{array}$ \\
$\begin{array}{l}\text { Practice pretest and } \\
\text { posttest }\end{array}$ & 0.129 & $\begin{array}{l}\text { Retain the null } \\
\text { hypothesis }\end{array}$ \\
\hline
\end{tabular}

The hypothesis testing used for data that wasn't normally distributed was the nonparametric Wilcoxon test rank. Confidence level that used in this research was $95 \%$. The test results was as follows:

Table 5 showed the $p$ value of Knowledge Pretest and Posttest was 0.675 , means that null hypothesis was accepted, which stated that there was no difference in knowledge before and after training. The $p$ value of Attitude Pretest and Posttest was 0.354 , means that null hypothesis was accepted, which stated that there was no difference in attitude before and after training. The $P$ value of Practice Pretest and Posttest was 0.129 , means that null Hypothesis was accepted, which stated that there was no difference in practice before and after training.

\section{DISCUSSION}

The results of pretest and posttest of the knowledge after the training had shown some increase in the percentage, but there were also some answers that shown a constant percentage. One answer item decreased. The increasing percentage in the teacher's knowledge was useful to develop a teacher's training program, which includes knowledge on oral health to provide oral health education in the school environment. After training, teachers will be able to play important role in the promotion of children's oral health. ${ }^{9}$

Some of the answers remain unchanged. It was due to the training time which was done in the afternoon, after school activities finished. The stagnancy can also caused by the tight schedule and curriculum, and the training was initial in this school. Lack of training and time in school curriculum identified as a major obstacle in the implementation of oral health education program in elementary schools. ${ }^{9}$ The results above indicated that the teachers need more training development. This was consistent with Baral et al. ${ }^{10}$ research which states that the health training program for teachers should be developed. It is aimed to reinforce learning. It can be done by academicians further and comprehensively, thus it can strengthen teachers' learning skills. ${ }^{10}$

The results of attitude posttest showed an increase in the percentage of some positive position statements and a decrease in the percentage of negative attitudes statement, however, there was also a decrease percentage of answers in positive answer. The above results were consistent with research conducted by Ramroop et al. ${ }^{9}$ in 2011 that stated the majority of teachers show a positive attitude towards oral health and its incorporation to the school curriculum. Teacher's attitudes towards their own involvement for developing oral health program at school was also positive. ${ }^{9}$

Teacher's practice concerning the proper time for tooth-brushing and the use of fluoridecontaining toothpaste showed an increasing percentage after the training. However, for shared-use of a toothbrush remains unchanged after the training. The item on how to brush the teeth showed various answer before training, and showed the same variation even after training. Therefore after training, the teachers were reminded on how to brush the teeth properly. It was important because they had to transfer the knowledge to the students after training. This occurred because the training was conducted in the afternoon after full-day teaching and learning activities which caused teachers following the training with minimum concentration.

The test results showed no difference between knowledge, attitude, and practice before 
and after training. The results was different with Ramroop et al. ${ }^{9}$ research which stated that the majority of teachers demonstrated positive attitudes toward oral health and its incorporation into the school curriculum. Teacher's involvement in school-based oral health education were also positive. Lack of training, resources, and time within the curriculum were identified as major barriers to the implementation of oral health education program in primary schools.

Ramroop et al. ${ }^{9}$ also stated that a developed teacher training programs that included oral health knowledge and an evidence-based approach to oral health education within a school setting could enable primary school teachers to play a significant part in oral health promotion for young children in Trinidad. The above description showed the importance of training repetitions for teachers to make them able to take a significant role in oral health promotion. ${ }^{9}$

Nyandindi et al. ${ }^{11}$ research stated that the teacher's knowledge of oral health matters and their skills in tooth-brushing were poor. This happened because generally, health lessons were not placed in the high priority, and also because of the shortage of time and materials for health educations and teacher's heavy workload at school. Therefore, organizing oral health training and encouraging teachers to undertake this task as part of oral health education was a necessity. ${ }^{12}$

The research results were also different with the research done by Dedeke et al. ${ }^{12}$ that mentioned a significant difference between the mean scores of the pre and post evaluations. This result occurred because in Dedeke et al. ${ }^{11}$ research, the training of was done more than twice, as opposed to the training in this research which was initially done in only one session. The above description indicates that the training should be done more than once to get good and significant results. ${ }^{12}$

Training is very important for teachers because most teachers in developing countries have poor knowledge and motivation about oral health which due to inadequate training about oral health. School teachers plays an important role in imparting appropriate and up-to-date knowledge to their students. The training can also improved the knowledge of school teachers regarding oral health. ${ }^{12}$

\section{CONCLUSIONS}

There was no impact of initial oral health training on teacher's knowledge, attitudes, and actions change.

\section{REFERENCES}

1. Riyanti E. Upaya peningkatan gigi dan mulut melalui perubahan perilaku anak. 2010. Available from: http://pustaka.unpad.ac. id/wpcontent/uploads/2010/06/upaya_ peningkatan_kesehatan_gigi_dan_mulut.pdf. p. 2.

2. National Basic Health Research (RISKESDAS) Dental health. Jakarta: The National Institute of Health Research and Development Ministry of Health Republic of Indonesia; 2013. p. 153.

3. Amsani D. Pengaruh leaflet dan penyuluhan terhadap perilaku kader kesehatan di Kecamatan Jatiluhur Kabupaten Purwakarta. Thesis Bandung: Fakultas Ekonomi Unpad; 2008. p. 5.

4. Sukiarko E. Pengaruh pelatihan dengan metode belajar berdasarkan masalah terhadap pengetahuan dan keterampilan kader kader gizi dalam kegiatan posyandu. Thesis. Semarang: Universitas Diponegoro; 2010. p. 5.

5. Solhi M, Shojaei Zadeh D, Seraj B, Faghih Zadeh S. The application of health belief model in oral health education. Iranian J Publ Health 2010;39(4):114-9.

6. Marguireta J, Treadwell HM, Northridege M. Community health worker and community health choices: promoting good health. Georgia, Atlanta:National Centre of Primary Care Morehouse School of Medicine; 2010. p. 5.

7. Sugiyono. Metode penelitian pendidikan: pendekatan kuantitatif, kualitatif, dan R\&D. Bandung: Alfabeta; 2010. p. 96.

8. Maharani, DA. Uji statistik dan estimasi besar sampel. Jakarta: Badan Penerbit Fakultas Kedokteran Universitas Indonesia; 2016. p. 37.

9. Ramroop V, Wright D, Naidu R. Dental health knowledge and attitudes of primary school teachers toward developing dental health education. West Indian Med J 2011 Oct;60(5):576-80.

10. Baral N, Gautam A, Lamsal M, Paudel 
BH, Lal Das BK, Aryal M. Effectiveness of teachers' training in assessment techniques: participants' perception. Kathmandu Univ Med J (KUMJ) 2011 Jul-Sep;9(35):189-92.

11. Nyandindi U, Palin PT, Milén A, Robison V, Kombe N, Mwakasagule S. Participation, willingness and abilities of school-teachers in oral health education in Tanzania. Commun Dent Health 1994Jun;11(2):101-4.

12. Dedeke AA, Osuh ME, Lawal FB, Ibiyemi O, Bankole 00, Taiwo JO et al. Effectiveness of an oral health care training workshop for school teachers: a pilot study. Ann Ib Postgrad Med 2013Jun;11(1):18-21. 